\title{
The Utilization of Technology to Improve English Speaking Skills
}

\author{
Andi Herlina \\ Maritime Academy of Veteran Republic of Indonesia (AMI) Makassar \\ Nuri Street, Makassar Indonesia \\ E-mail: agustitantu@yahoo.com
}

Received: September 20, 2014 Accepted: October 1, 2014 Published: November 20, 2014

doi:10.5296/jsel.v2i2.6665 URL: http://dx.doi.org/10.5296/jsel.v2i2.6665

\begin{abstract}
Technology-based assessment combining innovative methods and techniques is utilized to assess English language proficiency improvement. Such assessment will be regarded effective if language learner has a chance to utilize the technology device they have learnt. Conversely, conventional assessment method failed to denote what can be done from what they have learnt. This paper examines the utilization of different technology-based devices, such as computer, and conversation to assess English language proficiency. This alternative assessment method is different from conventional assessment that uses stationary. The paper aims at illustrating some activities to be performed by utilizing technology to assess and to monitor achievement of English language learner.
\end{abstract}

Keywords: Technology device, Assessment, English, Achievement 


\section{Introduction}

Some experts in the field of successful language learning state that success language proficiency assessment shall be authentic, valid, and reliable to be used (Hughes, 2003).

In general, authenticity refers to real world activity. Therefore, if the test is regarded authentic, it shall reflect real world activity. In fact, activity used in testing shall not be manipulative. The activity shall reflect communicative aspect of the language in real life communication.

Assessment has to test what shall be tested. Testing material is a kind of validity which shall reflect goal of the test to meet validity.

No less important than validity in assessment is reliability to which, in general, it refers to value consistency. In this case, conventional assessment method such as multiple-choice test which is still applied is less authentic and less valid since it does not reflect how language is used in communication with people in informal speech out of the class (Underhill, 1987). Simply put, conventional method is almost real alike.

According to considerations, many technology-based assessment methods may assist English teacher to find out what has been learnt by student to make it applicable in real life. An important matter to be shed some light on regarding this method is that it emphasizes at student's creativity and self-assessment which are an absence in conventional assessment method.

\section{Technology-based Assessment}

Differences in technology have dominated the world driven by its fast progress. This progress makes different technology use in different English teaching that assessment will be different too.

With this matter in mind, differences in technology may be utilized to assist teachers in student's language proficiency assessment, in general, and different language skills, in particular, without depending on conventional assessment method which the latter cannot reveal different skills achievement in an exact score. This is due to some factors to be taken into consideration by teachers in designing technology-based assessment.

Does the activity require student's creativity?; Does it reflect the real world?; Does it allow the student to use what they have learnt?; Does it allow student to use language skills in full capacity?; Does it increase their motivation?; Does it decrease affective filter?; Does it improve working group?; Is it quite reliable?; Is it valid?; Also, is it authentic?

Therefore, any activities designed to assess differences in language skills by utilizing different technology require a creative student. To perform the assessment, activity has to reflect real world communication. Simply put, it shall reflect what will be faced by English learner in society.

The other important factor in designing technology-based assessment is that activity shall allow student to use what they have learnt. Some teachers designed course examination by 
looking for materials unknown by students, instead of materials understood by students.

The activity shall also decrease affective filter and increase motivation. Frequently, it can be reached by allowing language teachers to design some assessment activity for one grade. Accordingly, teacher may divide class into two groups and invite every group to design some test items for the other group. For sure, this will increase motivation.

Substantial matter to be taken into consideration after designing activity is test item verification. In fact, test reliability and validity has to be verified first. Verification can be given by performing pilot study in purpose to make required changes.

By taking note of questions as named above, different technology such as computer, Internet, telephone and conversation, will be worth resources for both language learner and different language skills assessment.

Some activities which utilize computer, telephone, and voice recording will be applicable for formal and non-formal language learners. The activity will be usable to assess the progress of English language learner.

\subsection{Radio}

Radio is really helpful for listening comprehension practice. Yet, podcast will also be useful to improve other language skills, speaking skill for example. Accordingly, students can visit some websites that allow them to record and to upload their voice. Afterwards, other students can access the records easily. Foregoing, they will be able to leave a comment regarding what they have heard. The comment will help language learner to find out their weakness. Teacher, then, can take advantage of the records to assess student. Accordingly, students can discuss any topics for free based on information they have. They may also discuss any topics they like. Thus, they are not limited to teacher's will.

In purpose to increase scores validity, this criteria has to be increased complying with course goals.

Other activity for students is task. It is given to language learner group that allow them to finish the task out of the class. A student in the same group, then, should report the work. Please keep in mind that teacher has to pay attention on leaner's language proficiency and interest. In the other word, teacher should not force the topic on group that exceeds student's language proficiency. To prevent introduction to linguistically inappropriate topic to language learner, teacher may ask about their choices. For some topics proposed to language learner, the teacher can take one.

Concerning on applicable types of activity by means of different technology such as radio, it should be emphasized that some conventional activities are re-usable. Yet, the key point is that any activity designed for language learner shall be informed to other students via radio broadcasting.

\subsection{Conversation}

Many websites offer free live chat services which is pedagogically worth for language 
learner just like the language assessment. Accordingly, the role of social media, such as Twitter and Facebook broadly known as Web 2.0, for language learner has been analyzed by many researchers (for some are O'Reilly, 2005; Brown, 2008; Hall, 2008; Friesen, 2007; Siemens, 2005; Mason, 2008; Warschauer, 1996; Chun, 1994; Kern, 1995).

Therefore, terminology of "Web 2.0" refers to web application which makes participatory information sharing easy by user-centered design and collaboration in World Wide Web (O'Reilly, 2005). Web 2.0 allows the users to interact each other and collaborate with other users in social media dialog, it is different from website where the users are restricted to passive angle.

Web 2.0 offers possibilities to improve communication skills, self-expression, and comprehension (Hall, 2008). According to Brown (2008), social utilities such as Facebook and Twitter provide many communicative variances for online community development. Technology and this new mode of communication emerge in form of text and micro size information (Friesen, 2007), social-oriented interaction (Mason, 2008), and countless connection development between and among users and resources (Siemens, 2005).

Based on the previous researches regarding conversation of student in English, one hour per day will improve speaking skills at significant level (Warschauer, 1996; Chun, 1994; Kern, 1995). Accordingly, shy students will get more benefit from conversation room. However, key point of this case is that conversation will be beneficial if it is performed orally, instead of in written. If conversation with students in foreign country is possible, language learner will have chat with his colleague.

The teacher can propose a topic in class in every week and encourage students to join the group in different conversation room and exchange ideas with classmate or other student. Concerning on criteria of topic choices, the teacher shall take student's language proficiency and interest into consideration.

\subsection{Mobile Phone}

Concerning the utilization of various technologies in gaining fast access to authentic language input in informal setting, mobile phone has potential power to grasp large scale effect to language learner and language testing because of portability, multipurpose and cheapness of this device (Roschelle, 2003). Rapid advances in information and communication technologies make this mobile phone grow fast.

Emerging technology such as mobile phone shall be interpreted and applied completely in proper operating condition with being aware of constraints and challenges and also potential effect on cultural changes and practices today (Cobcroft et al., 2006).

Along with this progress, almost every student has one mobile phone today. Many students spend their time for hours per week on phone having a chat with classmate concerning school stuffs or other topics. If they are encouraged to keep talking in English, instead of native language, student's language proficiency will be much improved. The teacher may also ask the students to record their conversation and then submit the records to be assessed 
by the teacher or other student. At first, it is likely that students will get difficulties to meet this purpose. However, the frequent they have chat with friends in English, they will grasp pedagogical values by speaking in English. Moreover, they will also come up with familiar topic talked by other colleagues in English.

\subsection{Interview and Role Play}

Interview and role play seems like conventional. However, the point is student can choose a topic and then interview other student regarding the topic. If the interview is recorded on camera or mobile phone, it can be watched and assessed by the teacher. Besides, teacher may also encourage the students to listen interview recording and re-record it if they found any mistakes before submitting it to the teacher. Students can invite colleague to listen their conversation and evaluate the records. In this design, teacher is able to improve self monitoring regarding language learners' understanding to assist them.

\section{Conclusion}

The main purpose of this paper is to introduce some activities which can be combined with various technologies to be utilized by language learner and language assessment. Therefore, teacher can utilize computer, Internet, and mobile phone to encourage language learner and language assessment. However, teacher shall know how to assess language proficiency by means of this technology.

Concerning this matter, key point to be underlined is any applied method for language assessment by means of any technology, including mobile phone, shall be authentic, valid and reliable. Besides, the activity must be designed based on student's interest. By utilizing technology, teacher can associate language assessment and communication in the real world.

\section{References}

Brown, L. (2008). Student faces Facebook consequences. Toronto Star. [Online] Available: http://www.thestar.com/News/GTA/article/309855 (June 19, 2011).

Chun, D. M. (1994). Using computer networking to facilitate the acquisition of interactive competence. System, 22(1), 17-31. http://dx.doi.org/10.1016/0346-51X(94)90037-X

Cobcroft, R., Towers, S., Smith, J., \& Bruns, A. (2006). Mobile learning in review: Opportunities and challenges for learners, teachers, and institutions. Paper presented at Learning on the Move, Brisbane, Australia. [Online] Available: https://olt.qut.edu.au/udf/OLT2006/gen/static/papers/Low_OLT2006_paper.pdf (July 11, 2012).

Friesen, N. (2007). The Microlearning agenda in the age of educational media. In Lindner, M. \& Bruck, P. A. (Eds.), Micromedia and Corporate Learning: Proceedings of the 3rd International Micro-learning 2007 Conference (pp. 63-78). Innsbruck: Innsbruck UP

Hall, R. (2008). The Impact of the Read/Write Web on Learner Agency. E-Learning, 5(3), 285297. 
Hughes, A. (2003). Testing for language teachers (2nd Ed.). Cambridge: Cambridge University Press.

Kern, R. (1995). Restructuring classroom interaction with networked computers: Effects on quality and characteristics of language production. Modern Language Journal, 79(4), 457-476. http://dx.doi.org/10.2307/329999.

Mason, R. (2008). Can Social Software Change Teaching and Learning? Checkpoint Elearning. [Online] Available: http://www.checkpointelearning. com/article/5813.html (May 15, 2013).

O'Reilly, T. (2005). What is Web 2.0? Design Patterns and Business Models for the Next Generation of Software. O'Reilly Net November, 272013 [Online].Available: http://www.oreillynet.com/pub/a/oreilly/tim/news/2005/10/30/what-is-web-20.html (January 13, 2013).

Roschelle, J. (2003). Unlocking the learning value of wireless mobile devices. Journal of $\begin{array}{llll}\text { Computer } \quad \text { Assisted 260-272. } & \text { Learning, }\end{array}$ http://dx.doi.org/10.1046/j.0266-4909.2003.00028.x

Siemens, G. (2005). Connectivism: Learning as Network-Creation. Learning Circuits. [Online] Available: http://www.astd.org/LC/2005/1105_seimens.htm (July 21, 2010).

Underhill, N. (1987). Testing spoken language: A handbook of oral testing techniques. Cambridge: Cambridge Cambridge University Press.

Warschauer, M. (1996). Comparing face-to-face and electronic discussion in the second language classroom. CALICO Journal, 13(2), 7-26.

\section{Copyright Disclaimer}

Copyright for this article is retained by the author(s), with first publication rights granted to the journal.

This is an open-access article distributed under the terms and conditions of the Creative Commons Attribution license (http://creativecommons.org/licenses/by/3.0/). 